\title{
Fruit morphology in Galium section Platygalium (Rubiaceae) and its potential taxonomic significance
}

\section{Морфология плодов подмаренников (Galium, Rubiaceae) секции Platygalium и её значение для систематики}

\author{
A.M. Elkordy ${ }^{1}$, I.A. Schanzer ${ }^{2}$ \\ А.М. Элькорди ${ }^{1}$, И.А. Шанцер ${ }^{2}$ \\ ${ }^{1}$ Peoples' Friendship University of Russia, Miklukho-Maklaya str., 6, Moscow, 117198, Russia. E-mail: Elkordy3000@yahoo.com \\ ${ }^{1}$ Российский Университет Дружбы Народов, ул. Миклухо-Маклая, 6, Москва, 117198, Россия \\ ${ }^{2}$ Main Botanical Garden of Russian Academy of Sciences, Botanicheskaya str., 4, Moscow, 127276, Russia \\ ${ }^{2}$ Главный ботанический сад им. Н.В. Цицина РАН, ул. Ботаническая, 4, Москва, 127276, Россия \\ E-mail: schanzer@gmail.com
}

Key words: Rubiaceae, Galium, Platygalium, плод, морфология, поверхность мерикарпия, ключ. Ключевые слова: Rubiaceae, Galium, Platygalium, fruit, morphology, mericarp surface, key.

Summary. Fruit (mericarp) morphology of nine species from section Platygalium of the genus Galium from Russia were examined with light microscope and scanning electron microscope (SEM). Macro- and micromorphological characters, including fruit shape, size, and types of mericarp surface and indumentum are presented. Three types of mericarp surface were observed, glabrous, hairy with either hooked or straight hairs and tuberculate. The results agree with those of Pobedimova (1958), who classified the section Platygalium into three series. The mericarp characters also appear to be useful for species delimitation in this group.

Аннотация. Изучена морфология плодов (мерикарпиев) девяти видов секции Platygalium рода Galium с территории России под световым и сканирующим электронным микроскопом. Рассмотрены макро- и микроморфологические признаки, включая форму и размеры, а также типы поверхности и опушения мерикарпиев. Установлены три типа поверхности мерикарпиев: гладкая, опушенная крючковатыми или прямыми волосками и бугорчатая. Результаты согласуются с классификацией Е. Г. Победимовой (Pobedimova, 1958), разделявшей секцию на три ряда. Признаки мерикарпиев оказываются полезными также и для разграничения видов в этой группе.

\section{Introduction}

Rubiaceae (coffee family) is the fourth-largest angiosperm family, comprising approximately 660 genera and 11,500 species classified into 42 tribes (Robbrecht, Manen, 2006). Galium L. is one of the largest genera of the tribe Rubieae Baill. It comprises more than 600 species worldwide, mostly occuring in temperate areas, but also in alpine and arctic regions to subtropical and tropical zones at higher elevations (Chen and Ehrendorfer, 2011).

Galium is a typical member of Rubieae, sharing both morphological and molecular synapomorphies of this monophyletic group (Backlund et al., 2007; Bremer, Eriksson, 2009; Rydin et al., 2009a). However, infratribal taxonomy and classification of Rubieae is problematic, especially for the larger genera Asperula and Galium. A number of taxa within Asperula appear morphologically similar to Galium, differing only in corolla tube length, and these have been transferred from Asperula to Galium (Ehrendorfer, 1958; Ehrendorfer et al., 2005; Natali et al., 1995). Galium itself is problematic taxonomically, because taxa from different sections exhibit similar habit, many species are widely 
distributed and polymorphic, and species groups are often poorly differentiated both morphologically and geographically (Pobedimova, 1958).

Galium section Platygalium is a large and morphologically diverse group. No comprehensive, worldwide treatment exists for this section (Ehrendorfer et al., 2005). However, from a review of various floras, the section comprises at least 70 species (Dempster, 1981, 1982; Dempster, Stebbins, 1968; Ehrendorfer et al., 2005; Ehrendorfer et al., 1976; Ehrendorfer, Schönbeck-Temesy, 1982; Pobedimova, 2000; Yamazaki, 1993). The section is distributed worldwide with centers of diversity in eastern Asia, eastern North America, the Mediterranean, and the Caucasus (Ehrendorfer et al., 2005 ). Taxa are hermaphroditic and bear dry fruits that are glabrous or covered with hooked to straight hairs (Ehrendorfer et al., 1976; Ehrendorfer et al., 2005; Ehrendorfer, Schönbeck-Temesy, 1982; Pobedimova, 1958, 2000).

In «Flora Orientalis» Boissier (1881) reported 91 species of the genus Galium divided into three sections: section (I) Eugalium, section (II) Aparine, and section (III) Cruciata. Section (I) Eugalium is classified into four unranked groups: 1. Platygalia, 2. Leiogalia, 3. Chromogalia, and 4. Ceratocarpa. The group (1) Platygalia, includes the following species: G. boreale L., G. rubioides L., and G. valantioides Bieb. (Tab. 1). Pobedimova (1958) in the «Flora USSR» regarded Platygalia at the rank of section and reported 11 species within it, divided into 3 series, Rubioidea, Borealia and Valantioidea (Tab. 1). Series Rubioidea includes G. rubioides, G. articulatum Lam., G. physocarpum Ledeb., G. volgense Pobed., and G. ussuriense Pobed.; series Borealia includes G. boreale, G. amblyophyllum Schrenk, G. turkestanicum Pobed., G. amurense Pobed., G. septentrionale Roem. et Schult., and G. mugodsharicum Pobed.; series Valantioidea includes only $G$. valantioides.

According to the World Checklist of Rubiaceae (Govaerts et al., 2011), most of the species reported by Pobedimova (1958) in the «Flora USSR» have been reduced to synonyms of either $G$. boreale or G. rubioides. Thus, G. articulatum, G. physocarpum, $G$. volgense, and $G$. mugodsharicum are regarded there as synonyms of $G$. rubioides, while G. ussuriense, G. amurense, and G. septentrionale as synonyms of $G$. boreale.

Galium section Platygalium has not been treated systematically and monographically to date. The systematic treatment of this group is difficult for the following reasons: species are often similar in habit, highly polymorphic, and weakly differentiated geographically. Galium boreale and $G$. rubioides belong to a polyploid complex with a widespread circumpolar distribution in the northern Hemisphere. The complex comprises rare diploids $(2 \mathrm{n}=2 \mathrm{x}=22)$, tetraploids $(2 \mathrm{n}=4 \mathrm{x}=44)$, hexaploids $(2 \mathrm{n}=6 \mathrm{x}=66)$, and higher polyploids

Table 1

List of the studied species of Galium and their taxonomic positions according to different treatments

\begin{tabular}{|c|c|c|c|c|c|}
\hline № & Taxon & Boissier (1881) & Pobedimova (1958) & $\begin{array}{c}\text { Ehrendorfer et al. } \\
(1976)\end{array}$ & $\begin{array}{c}\text { Govaerts et al. } \\
(2011)\end{array}$ \\
\hline 1 & G. articulatum & - & $\begin{array}{l}\text { Section: Platygalia } \\
\text { Series: Rubioidea }\end{array}$ & - & $\begin{array}{l}\text { Synonym of } \\
\text { G. rubioides }\end{array}$ \\
\hline 2 & G. rubioides & $\begin{array}{c}\text { Section Eugalium } \\
\text { Platygalia }\end{array}$ & $\begin{array}{l}\text { Section: Platygalia } \\
\text { Series: Rubioidea }\end{array}$ & Section: Platygalium & Accepted \\
\hline 3 & $\begin{array}{l}\text { G. physocarpum } \\
\text { (= G. volgense) }\end{array}$ & - & $\begin{array}{l}\text { Section: Platygalia } \\
\text { Series: Rubioidea }\end{array}$ & - & $\begin{array}{l}\text { Synonym of } \\
\text { G. rubioides }\end{array}$ \\
\hline 4 & G. ussuriense & - & $\begin{array}{l}\text { Section: Platygalia } \\
\text { Series: Rubioidea }\end{array}$ & - & $\begin{array}{c}\text { Synonym of } \\
\text { G.boreale }\end{array}$ \\
\hline 5 & G. boreale & $\begin{array}{c}\text { Section Eugalium } \\
\text { Platygalia }\end{array}$ & $\begin{array}{c}\text { Section: Platygalia } \\
\text { Series Borealia }\end{array}$ & Section: Platygalium & Accepted \\
\hline 6 & G. amurense & - & $\begin{array}{l}\text { Section: Platygalia } \\
\text { Series Borealia }\end{array}$ & - & $\begin{array}{c}\text { Synonym of } \\
\text { G.boreale }\end{array}$ \\
\hline 7 & G. mugodsharicum & - & $\begin{array}{c}\text { Section: Platygalia } \\
\text { Series Borealia }\end{array}$ & - & $\begin{array}{l}\text { Synonym of } \\
\text { G. rubioides }\end{array}$ \\
\hline 8 & G. septentrionale & - & $\begin{array}{c}\text { Section: Platygalia } \\
\text { Series Borealia }\end{array}$ & - & $\begin{array}{c}\text { Synonym of } \\
\text { G.boreale }\end{array}$ \\
\hline 9 & G. valantioides & $\begin{array}{c}\text { Section. Eugalium } \\
\text { Subsections: } \\
\text { Platygalia }\end{array}$ & $\begin{array}{l}\text { Section: Platygalia } \\
\text { Series Valantioidea }\end{array}$ & - & Accepted \\
\hline
\end{tabular}


(12x). 4x and 6x cytotypes occur throughout Europe (Kliphuis, 1986), 12x cytotype has been reported for G. rubioides. Many morphological intermediates occur throughout Eurasia. The status of all these taxa remains uncertain without detailed cytotaxonomic analyses (Ehrendorfer et al., 1976).

The scanning electron microscope (SEM) has been used by various authors during the past years for investigating details of the surface structure of pollen and seed. The SEM microscopy of seeds has become a routine technique for furnishing information on seed coat morphology (Heywood, 1969). Abdel Khalik et al. (2008) recommended SEM in their studies of the structure of fruits and seeds ornamentation in the genus Galium as being useful for taxonomic studies. In particular, Balde (2013) proved and distinguished the specific independence of $G$. amurense from closely related species $G$. boreale on the basis of morphological characteristics revealed with SEM.

The present study deals with micro- and macromorphological characters of fruit (mericarps) sculpture and indumentum in taxa of the section Platygalium from Russia in order to establish their usefulness for further taxonomic work. Fruits of Galium are of schizocarpic nature, composed of two mericarps, each mericarp having only one seed. They are usually regarded as important for Galium taxonomy at infrageneric and species level.

\section{Materials and methods}

The present study is based on the materials kept at the Herbarium (MHA) of the Main Botanical Garden of Russian Academy of Sciences. For the purposes of the study, all the specimens were determined according to the narrow treatment by Pobedimova (1958) using the key and descriptions given in the «Flora USSR». Only mature fruits were taken for investigation. Dried fruits were soaked in boiling water for 2-4 minutes, to compensate for shrinkage and examined by light microscope, with $10-15$ fruits for each taxon chosen to cover the range of variation. Measurements were standardized with ocular micrometer. The fruit surface microsculpture and indumentum characters were examined with a LEO 1430 VP Scanning Electron microscope.

List of Galium specimens used for light and scanning electron microscope studies:

1. G. articulatum: Volgograd Prov., 19 IX 1974, E. Gogina, A. Matzenko .

2. G. rubioides: Volgograd Prov., 03 VIII 1993 I. Schanzer, G. Klinkova.
3. G. physocarpum: Volgograd Prov., 30 VIII 1985, N. Belyanina.

4. G. ussuriense: Polar Urals, 19 VIII 1964, A. Skvortsov, V. Filin.

5. G. boreale: Estonia, 15-16 VIII 1986, A. Skvortsov, V. Bochkin, N. Shevyreva.

6. G. amurense: Khabarovsk surroundings, 10 VII 1980. V. Kuvaev.

7. G. mugodsharicum: Smolensk Prov., 18 IX 1971, V. Makarov, G. Proskuryakova.

8. G. septentrionale: Polar Urals, Tyumen Prov., 04 VIII 1991, T. Konovalova, N. Shevyreva.

9. G. valantioides: N Caucasus, Pyatigorsk neighbourhood, 03 VII 1976, E. Gogina.

\section{Results}

\section{Mericarp shape and size}

Mericarp shape among the investigated taxa is more or less the same, however it may be either subglobose or subglobose inflated (swollen), with the pericarp loosely surrounding seeds (Tab. 2). It is subglobose in $G$. ussuriense, G. boreale, $G$. amurense, G. valantioides, G. septentrionale, and G. mugodsharicum, while being to different degree inflated (swollen) in G. physocarpum, G. articulatum, and G. rubioides (Tab. 2). Mericarp shape shows no highly significant differences among the studied taxa.

Mericarp dimensions do not vary greatly among the examined taxa. They range from 1.0-1.5 $\times 1.0$ $2.0 \mathrm{~mm}$ in G. mugodsharicum to $3.0-5.0 \times 2.5-3.5$ $\mathrm{mm}$ in G. amurense (Tab. 2). However, we can say that among the studied species those having fruits with inflated pericarp, do have larger fruits as well.

\section{Mericarp indumentum}

Among the studied species, mericarp surface is glabrous in those with inflated pericarp, i.e. $G$. articulatum (Plate I: 1A, B), G. rubioides (Plate I: 2A, B), G. physocarpum (Plate I: 3A, B), and G. ussuriense (Plate I: 4A, B). In other species it is covered with hairs or tubercules of various length, shape and density. Thus, in $G$. boreale mericarps are densely covered with uncinate hairs 0.3-0.4 mm long (Plate II: 5A, B). In G. amurense mericarps are densely setose with long straight hairs of $0.50-0.65 \mathrm{~mm}$ long (Plate II: 6A, B). They are scabrous with short hooked setae $0.10-0.15 \mathrm{~mm}$ in G. mugodsharicum (Plate II: 7A, B); sparsely covered with hooked hairs $0.20-0.25 \mathrm{~mm}$ in $G$. septentrionale (Plate II: 8A, B) and glabrous to tuberculate in G. valantioides (Plate III: 9A, B). 
Table 2

Mericarp descriptions of studied Galium species

\begin{tabular}{|c|l|c|c|c|}
\hline$№$ & \multicolumn{1}{|c|}{ Taxon } & Mericarp Shape & Mericarp size in (mm) & Mericarp Surface \\
\hline 1 & G. articulatum & Subglobose & $1.0-1.5 \times 2.0-2.5$ & Glabrous \\
\hline 2 & G. rubioides & Subglobose & $1.5-2.0 \times 2.5-3.0$ & Glabrous \\
\hline 3 & $\begin{array}{l}\text { G. physocarpum } \\
\text { (= G. volgense) }\end{array}$ & Subglobose & $1.5-2.0 \times 2.0-3.0$ & $\begin{array}{c}\text { Glabrous, inflated (swollen), pericarp } \\
\text { loosely surrounding the seeds }\end{array}$ \\
\hline 4 & G. ussuriense & Subglobose & $3.0-5.0 \times 2.5-3.5$ & Glabrous \\
\hline 5 & G. boreale & Subglobose & $1.5-2.0 \times 2.0-2.5$ & Densely uncinate \\
\hline 6 & G. amurense & Subglobose & $1.0-1.5 \times 1.5-2.0$ & Densely setose with long straight hairs \\
\hline 7 & G. mugodsharicum & Subglobose & $1.0-1.5 \times 1.0-2.0$ & Scabrous with short hooked setae \\
\hline 8 & G. septentrionale & Subglobose & $1.0-1.5 \times 1.0-2.0$ & Glabrous to tuberculate \\
\hline 9 & G. valantioides & Subglobose & $1.0-2.0 \times 1.5-2.5$ & \\
\hline
\end{tabular}

\section{Discussion}

Our results seem to prove the correspondence between the mericarp characters and the traditional classification within the section Platygalium (Pobedimova, 1958). Based on the main external fruit morphology, two groups have traditionally been distinguished, with glabrous and hispid fruits (Boissier, 1881). Our results based on morphological characters of mericarps agree with classification of the section Platygalium into three series (Pobedimova, 1958), since three types of mericarp surface were revealed, glabrous (Plate I), hairy with either hooked or straight hairs (Plate II), and tuberculate (Plate III). The glabrous type of mericarps is characteristic of $G$. rubioides, G. articulatum, G. physocarpum and G. ussuriense which belong to the series Rubioidea, while $G$. boreale, G. amurense, G. septentrionale and G. mugodsharicum with hairy mericarps belong to the series Borealia (Pobedimova, 1958). The series Valantioidea includes $G$. valantioides which has tuberculate mericarp surface.

Moreover, we found out that detailed characteristics of mericarp hairiness were useful to delimitation of four closely similar species $(G$. boreale, $G$. amurense, $G$. septentrionale and $G$. mugodsharicum) from the series Borealia. Thus, $G$. boreale has mericarps densely covered with hooked hairs $0.3-0.4 \mathrm{~mm}$ long, G. amurense has mericarps covered with long, dense, straight, hairs 0.50-0.65 $\mathrm{mm}$ long, while in G. septentrionale mericarps are sparsely covered with short hooked hairs $0.20-0.25$ mm long. Finally, G. mugodsharicum has mericarps scabrous with short hooked setae $0.10-0.15 \mathrm{~mm}$ long. Mericarp characters were also found useful to distinguish between G. physocarpum and some other closely related species of the series Rubioidea. Here, however, G. articulatum, G. ussuriense and G. rubioides seem to be indistinguishable from each other neither by mericarp shape and dimensions, nor by the details of its surface. We suggest treating them all under G. rubioides.

Within the framework of this study, it has become clear that the present species concept for the section Platygalium is still very vague and needs further careful and critical morphological, palynological, karyological and molecular examination. Furthermore, the existence of hybridization between both closely related species and species from different subsections leading to appearance of plants with intermediate character combinations cannot be excluded. Due to these recognized problems, both the key below, and the data on mericarp dimensions in tables 1 and 2 are preliminary, and only enable to recognize typical members of the taxa studied.

\section{Key to the studied species based on mericarp characters:}

1a. Mericarps hairy 2

1b. Mericarps glabrous or tuberculate ........... 5

2a. Mericarps covered with long, dense, straight hairs G. amurense

2b. Mericarps covered with hooked hairs ...... 3

3a. Mericarps covered with dense hooked hairs G. boreale

3b. Mericarps scabrous or sparsely hooked hairs 4

4a. Mericarps scabrous with short hooked setae G. mugodsharicum

4b. Mericarps covered with sparsely hooked hairs G. septentrionale

5a. Mericarps tuberculate .......... G. valantioides

5b. Mericarps glabrous 6

6a. Pericarp loosely surrounding the seed G. physocarpum

6b. Pericarp more or less adhere to the seed, rugose

G. rubioides, G. articulatum, G. ussuriense 7 

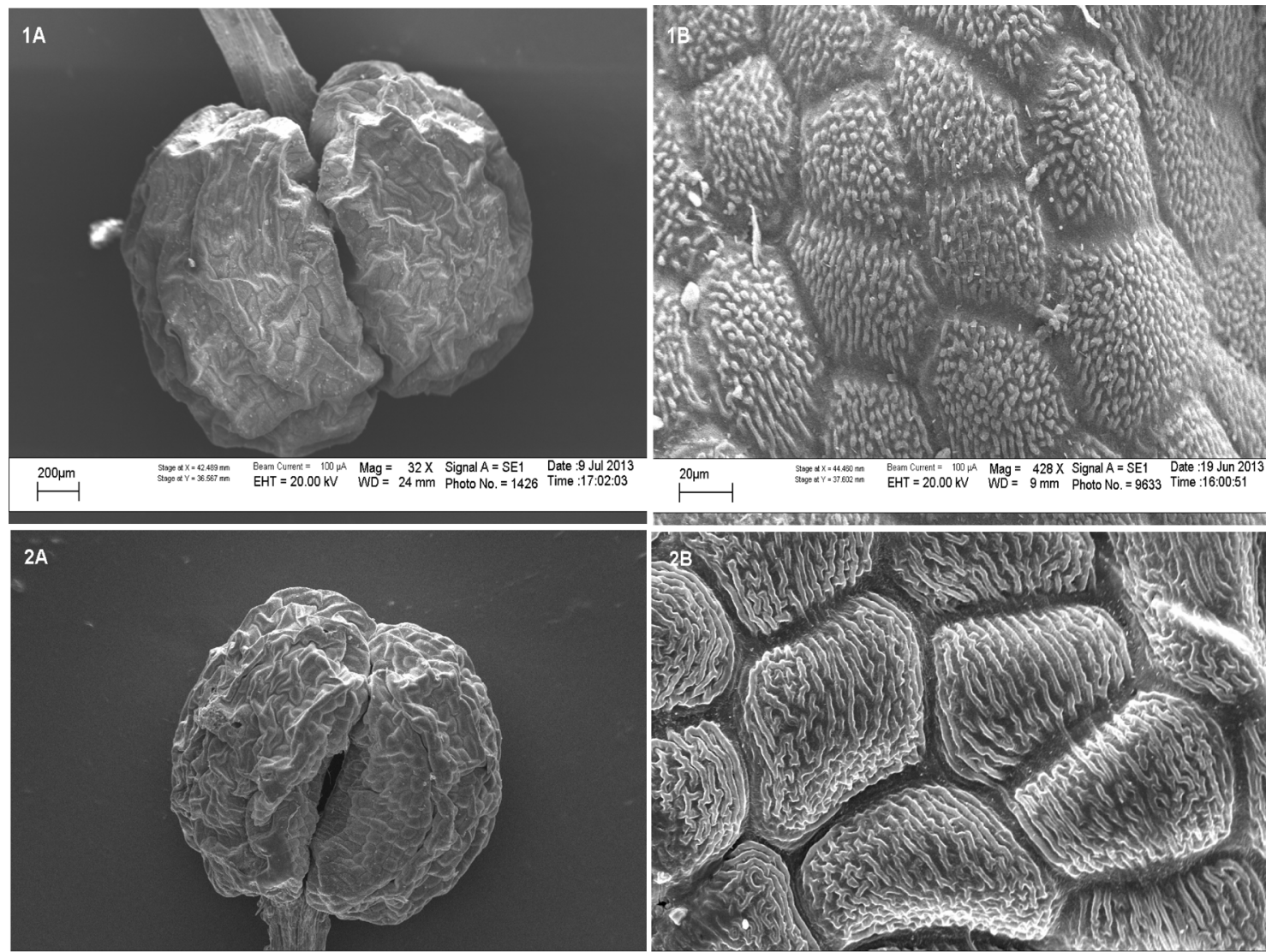

$20 \mu \mathrm{m}$

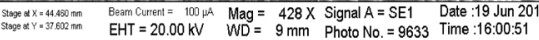
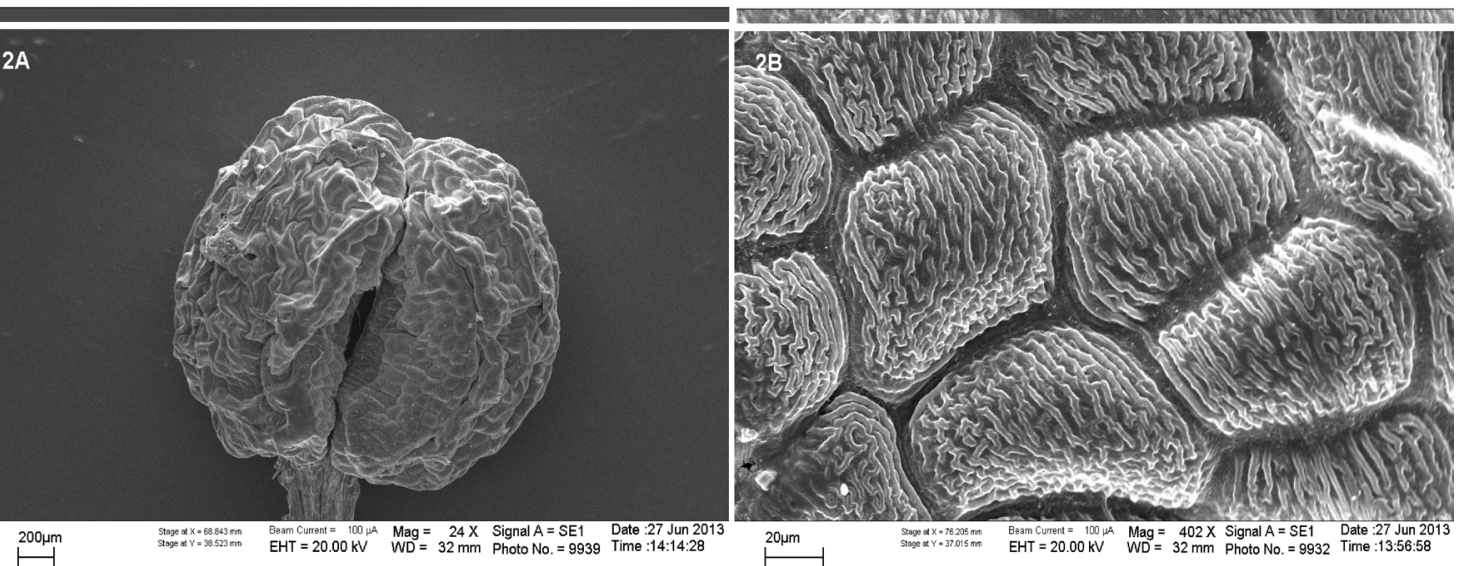

$\stackrel{20 \mu m}{\longmapsto}$

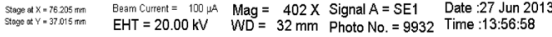
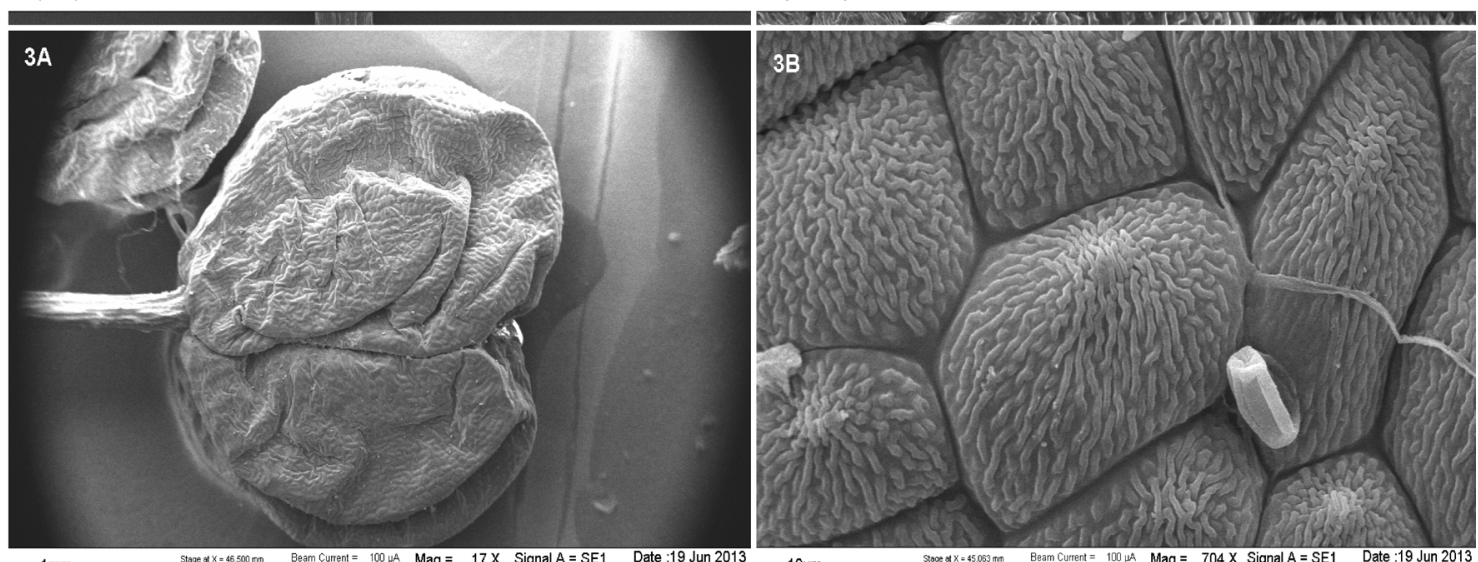

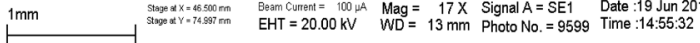
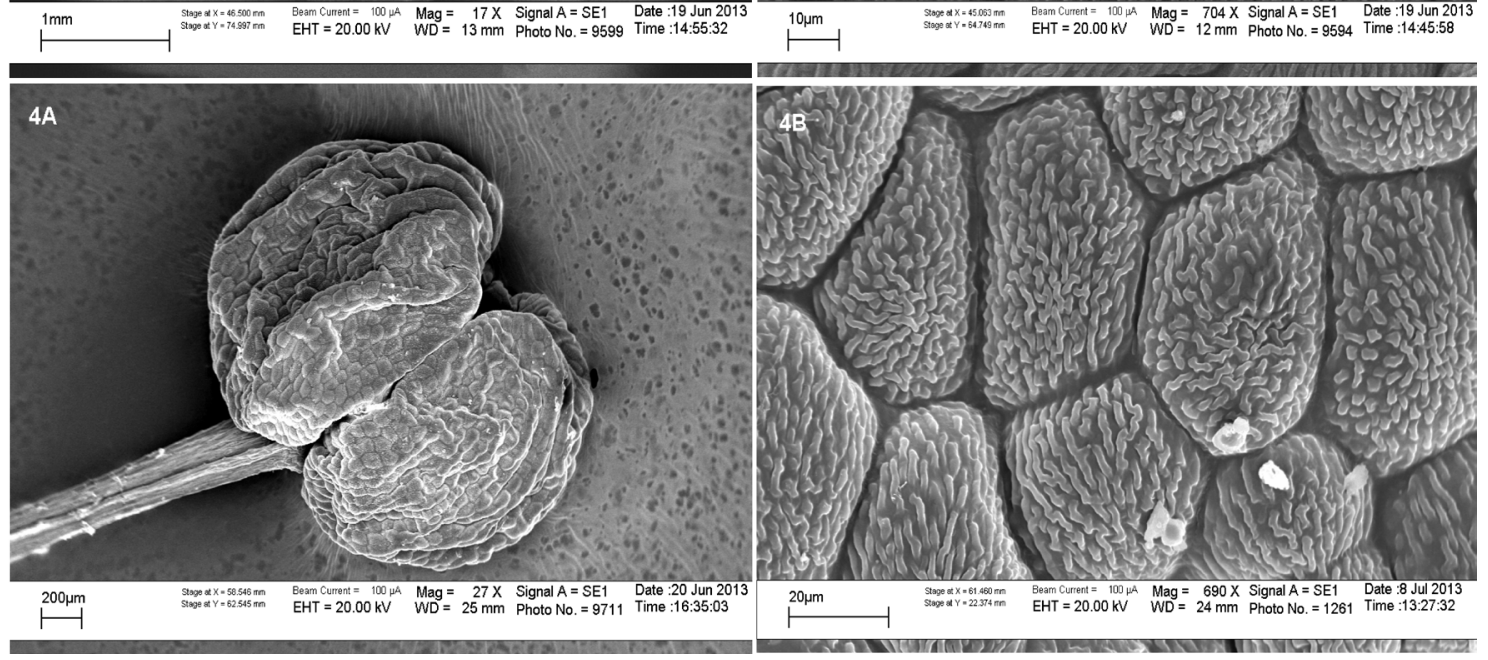

Plate I. SEM photographs of mericarps. A - entire mericarps, B - part of mericarp surface, enlarged.

1A, B - Galium articulatum; 2A, B - G. rubioides; 3A, B - G. physocarpum; 4A, B - G. ussuriense. 


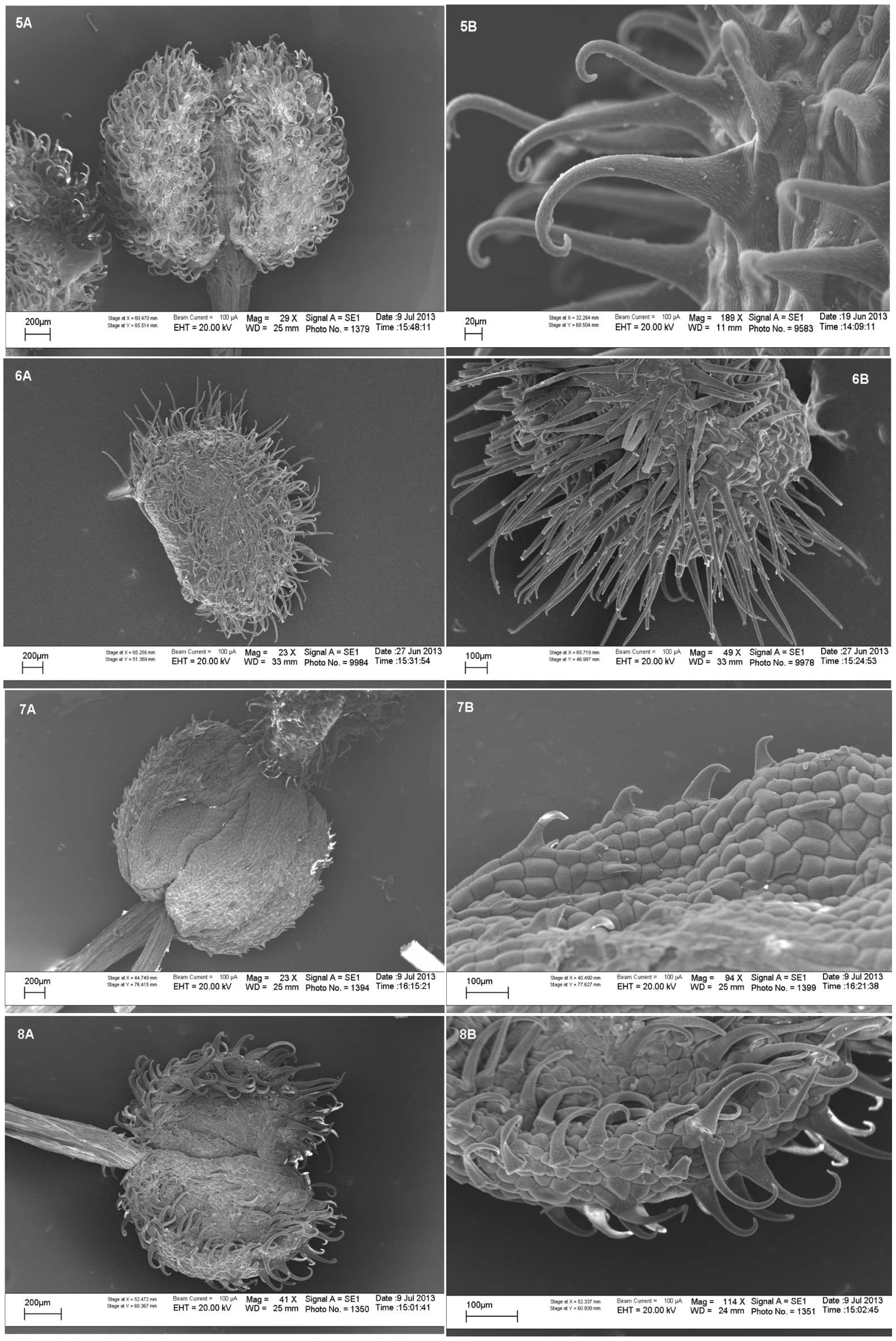

Plate II. SEM photographs of mericarps. A - entire mericarps, B - part of mericarp surface, enlarged. 5A, B - Galium boreale; 6A, B - G. amurense; 7A, B - G. mugodsharicum; 8A, B - G. septentrionale. 


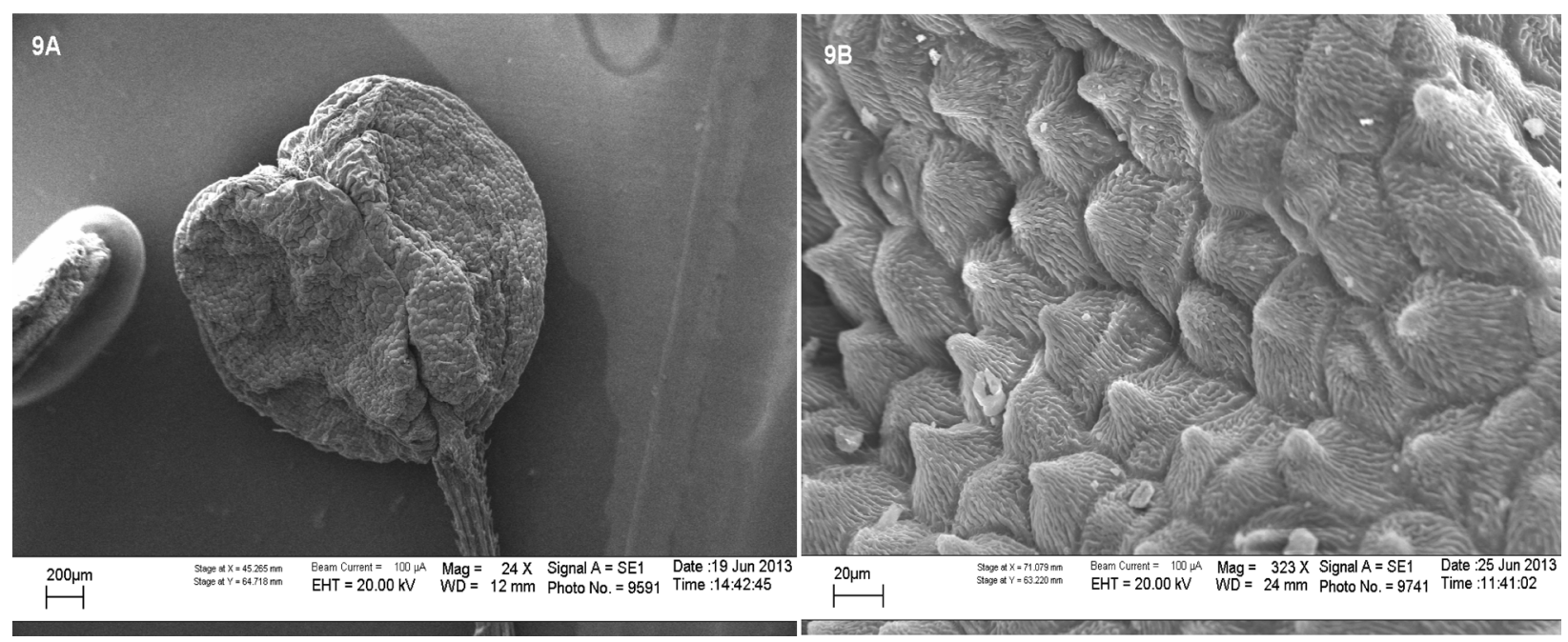

Plate III. SEM photographs of mericarps. A - entire mericarps, B - part of mericarp surface, enlarged.

9A, B - Galium valantioides.

\section{REFERENCES}

Abdel Khalik K., Abd El-Ghani M.M. \& El Kordy A. Fruit and seed morphology in Galium L. (Rubiaceae) and importance for taxonomic identification // Act. Bot. Croat., 2008. - No. 67. - P. 1-20.

Backlund M., Bremer B., Thullin M. Paraphyly of Paederieae, recognition of Putorieae and expansion of Plocama (Rubiaceae-Rubioideae) // Taxon, 2007. - No. 56. - P. 315-328.

Balde E. On specific independence of Galium amurense Pobed. (Rubiaceae) // Novosti Sist. Vyssh. Rast. [Novit. Syst. Pl. Vasc.], 2013. - Vol. 44. - P. 206-213. [In Russian] (Балде E.A. О видовой самостоятельности Galium amurense Pobed. (Rubiaceae) // Новости сист. высш. раст., 2013. - Т. 44. - С. 206-213).

Boissier E. Flora Orientalis. - Vol. 3. Calyciflorae gamopetalae. - Basileae: H. Georg, 1881. - 1033 p.

Bremer B., Eriksson T. Time tree of Rubiaceae. phylogeny and dating the family, subfamilies, and tribes // International Journal of Plant Sciences, 2009. - No. 170. - P. 766-793.

Dempster L.T. The genus Galium (Rubiaceae) in South America. II // Allertonia, 1981. - No. 2. - P. 393-426.

Dempster L.T. The genus Galium (Rubiaceae) in South America. III // Allertonia, 1982. - No. 3. - P. 211-258.

Dempster L.T., Stebbins G.L. A cytotaxonomic revision of the fleshy-fruited Galium species of the Californias and southern Oregon (Rubiaceae) // University of California Publications in Botany, 1968. - No. 46. - P. 1-52 .

Ehrendorfer F. Critical notes on Turkish Rubiaceae. // Notes from the Royal Botanic Garden, Edinburgh, 1958. No. 22 - P. 323-401.

Ehrendorfer F., Krendl F., Puff C. Galium L. // T.G. Tutin et al. [eds.]. Flora Europaea. - New York: Cambridge University Press, 1976. - Vol. 4, - P. 14-36.

Ehrendorfer F., Schönbeck-Temesy E. Galium L. // P.H. Davis [ed.]. Flora of Turkey and the East Aegean Islands. - Edinburgh: Edinburgh University Press, 1982. - Vol. 7. - P. 767-849.

Ehrendorfer F., Schönbeck-Temesy E., Puff C., Rechinger W. Flora Iranica. - №. 176. Rubiaceae. Vienna: Verlag des Naturhistorischen Museums Wien, 2005. - 287 p.

Govaerts R., Ruhsam M., Andersson L., Robbrecht E., Bridson D.M., Davis A.P., Schanzer I., Sonké B. World Checklist of Rubiaceae. Royal Botanic Gardens, Kew, 2011. Available at: http://www.kew.org/wcsp/rubiaceae

Heywood V.H. Scanning electron microscopy in the study of plant materials // Micron, 1969. - No. 1 - P. 1-14.

Kliphuis, E. Cytotaxonomic investigations on some species of the genus Galium (Rubiaceae) from the Balkans///

Nord. J. Bot., 1986. - No. 6. - P. 15-20.

Natali A., Manen J.-F., Ehrendorfer F. Phylogeny of the Rubiaceae-Rubioideae, in particular the tribe Rubieae: Evidence from a non-coding chloroplast DNA sequence // Annals of the Missouri Botanical Garden, 1995. No. 82. - P. 428-439.

Natali, A., Manen J.-F., Kiehn M., Ehrendorfer F. Tribal, generic and specific relationships in the RubioideaeRubieae (Rubiaceae) based on sequence data of a cpDNA intergene region // Opera Botanica Belgica, 1996. No.7. - P. 193-203.

Pobedimova E.G. Galium L. // Shishkin B.K. [ed.]. Flora USSR. Moskva, Leningrad: Izd. AN SSSR, 1958. - Vol. 23. - P. 287-381 [in Russian]. (Победимова E.Г. Galium L. // Флора СССР / Под ред. Б.К. Шишкина. - М.-Л.: Изд-во АН СССР, 1958. - Т. 23. - С. 287-381). 
Robbrecht E., Manen J.-F. The major evolutionary lineages of the coffee family (Rubiaceae, angiosperms). Combined analysis (nDNA and cpDNA) to infer the position of Coptosapelta and Luculia, and supertree construction based on $r b c L$, rps 16, trnL-trnF and $a t p B-r b c L$ data. A new classification in two subfamilies, Cinchonoideae and Rubioideae // Systematics and Geography of Plants, 2006. - No. 76. - P. 85-146.

Rydin C., Kainulainen K., Razafimandimbison S.G., Smedmark J.E.E., Bremer B. Deep divergences in the coffee family and the systematic position of Acranthera // Plant Systematics and Evolution, 2009. - No. 278. P. 101-123.

Chen T., Ehrendorfer F. Galium L. // Z.Y. Wu, P.H. Raven, D.Y. Hong [eds.]. Flora of China. - Vol. 19. Cucurbitaceae through Valerianaceae, with Annonaceae and Berberidaceae. - Beijing: Science Press, and St. Louis: Missouri Botanical Garden Press, 2011. - P. 104-141.

Yamazaki T. Rubiaceae // K. Iwatsuki et al. [eds.]. Flora of Japan. - Tokyo: Kodansha, 1993. - Vol. 3a. P. 206-240. 